\title{
Derrida on the Death Penalty
}

\author{
Matthias Fritsch, Concordia University, Montréal
}

\begin{abstract}
Responding to Derrida's Death Penalty Seminar of 1999/2000 and its interpretation by Michael Naas, the paper argues that Derrida's deconstruction of the theological-political concept of the sovereign right over life and death in view of abolishing capital punishment should be understood in terms of the unconditional renunciation of sovereignty as called for in Derrida's later political writings, Rogues in particular. This reading takes seriously what is here called the functional need for a 'theological' moment in sovereignty beyond a merely historicist or genealogical interpretation of the European monotheistic heritage. Further, this reading asks how Derrida may follow through on his goal of developing the allegedly first principled philosophical stance against capital punishment. To this end, the paper assembles some ingredients of this complex but 'unconditional' abolitionism, one that doubts our comprehension of and active relation to death to the point of questioning the common sense distinctions among murder, suicide, and legal putting to death. The paper concludes that for Derrida, letting another die of hunger or AIDS may be understood as a form of death sentence, so that a deconstructive abolitionism puts into question the good conscience of sovereign agency.
\end{abstract}

\section{Keywords}

Derrida; sovereignty; political theology; death penalty; abolitionism

In assuming the distinctive honor of responding to Michael's paper, to his way of tilling the soil for us to better read Derrida's Death Penalty Seminars, allow me to concentrate on two motifs that I believe are close to Michael's concerns. (1) The first concerns the way we are to understand what Michael calls the "theologico-political heritage" of which he says its deconstruction characterizes Derrida's "overall project" (5, 11). (2) The second motif deals with the abolitionism of which Michael says that Derrida's

main objective in the seminar would be to ... develop his own, let us call it, more "philosophical," less theological, less strictly Judeo-Christian, more universalizable, maybe even more "Enlightened" abolitionism (p. 19). 
I would like to suggest that we situate these two motifs in their interrelation to Derrida's attempt, as Rogues has it, to "separate", despite their "inseparability", the "exigency of sovereignty in general" from "the unconditional exigency of the unconditioned" (Derrida 2005: 141/195-196). For, as Michael writes in Derrida From Now On, Derrida's

laïcité consists in a radical critique of the "theologico-political" in the name or under the aegis of an unconditionality (the other, the event, justice) that exceeds and ultimately disrupts all sovereignty (Naas 2008:12).

To understand Derrida's interest in the death penalty and in developing a "principled" and "consistent" abolitionism (Derrida 2004: 142), we must link the latter to an unconditional affirmation that renounces sovereignty.

(1) Turning then to the 'onto-theo-political' heritage, I believe the Death Penalty Seminars are admirably clear that the 'theological' in sovereignty is not just - though it is that, too - a matter of the historical sources that Western states happen to have inherited. In understanding what is 'theological' in the 'political', it is helpful to distinguish a (a) semantic-historical from a (b) functional interpretation of Derrida's occasional claims to purity, to absoluteness, to the unconditional, and here also to 'the theological' in sovereignty.

(a) In the context of the death penalty, the semantic-historical reading ${ }^{1}$ would conclude that it still belongs to the inherent meaning of sovereignty to execute human beings because, historically, sovereignty is a notion inherited from the idea of God as the absolute power and true sovereign to whom belongs the unconditional right over life and death above any norm and beyond any positive law. This would be so because of Plato's the Good beyond being (Derrida 2005: 137-140), Aristotle's unmoved mover as "the life 
that exceeds the life of human beings" (Derrida 2005: 15/35), and the way these came to be interpreted in light of the Judeo-Christian, the biblical creator-God. We can thus trace a line from ancient Athens and Jerusalem, to the medieval God as sovereign ruler over creation, and then from the divine right of the king as God's representative on earth (as the Pope still is in the Vatican), to the democratic revolution that, despite beheading the king, replaces God with 'the people' as indivisible sovereign. Implicit in this historicist reading might be the objective to seek to finally shake off this onto-theological heritage so as to enter into a truly 'secular' age. Toward the end of his paper (p. 22), Michael recalls that Derrida "has always pursued 'as far as possible the necessity of a hyperatheological discourse"” (Derrida 2004: 166).

However, in this dense but crucial last page of his paper, Michael also writes that this "hyper-atheological discourse" is, as deconstruction was from the beginning, only one side of a "double gesture", the other gesture consisting in "not ceasing to meditate on Abrahamic culture" without any desire "to destroy or to disqualify" it so as to avoid the idea that one can just "pass through" a heritage (Derrida 2004: 165). In problematizing the idea that one can one leave behind the ontotheological tradition by way of the greater awareness that deconstruction would promise to deliver, Derrida should be seen to point to reasons for sovereignty's claim to 'theological' absoluteness that, while taking on singular features in European heritage, are not just empirical and historical. It is here that we move to what I called the functional (rather than semanticist-historicist) interpretation.

(1b) For to think "the theological" in its absoluteness is also to first of all give oneself the means to think the functional need of sovereignty for an absolute moment above the law, one that cannot be captured or understood, regardless of heritage, without the right to the 
exception as exception to right and law. The functional reading of the theological absoluteness in sovereignty recognizes that, given the différantial constitution of identity, power, and selfhood, the latter can never take itself as established but must decide each time anew to preserve itself 'ipsocratically' in and through otherness, including other selves and foreign powers (Derrida 2005: 17/38). Self-preservation happens by way of and in reaction to the unconditional errancy of the event, a differantial errancy that requires re-affirmation of both the self to be preserved and the others who are needed for its constitution.

These others, in their alterity, also make it necessary for the self to be relaunched each time, to promise itself toward the unpredictable eventfulness of the event, the openness of the future that includes the self's own death. No sovereign self without welcoming gesture toward an other that threatens the self with its demise. In affirming itself, the self affirms the other that it must also cast out and keep at bay. ${ }^{2}$ Selfpreservation thus calls for decisions about friend and enemy, where the very lack of a pre-given self, one that would underlie its manifestations, implies the eventual indiscernibility, even the "convertibility" of friend and enemy, as Derrida argued against Schmitt in Politics of Friendship. Thus the aporia of the sovereign decision as "the decision of the other in me" (Derrida 1997: 69), as Derrida recalls at the outset of the Death Penalty Seminar (DP1a4). ${ }^{3}$

Due to the constitutive exposure to errancy and the lack of any surety as to the 'self' to be preserved, self-preservation cannot hold on to pre-given guardrails or norms, even those it might have given itself, but must claim its right to overturn and contradict its own rules, the rules by means of which it also seeks to define itself. In the case of the 
political, the sovereign must claim to suspend the law and thus remain above and beyond its own, in fact incompleteable and fragile identity. And it is in this suspension of the law and the decision regarding the enemy that we find the justification of the death penalty. In an exceptional situation, "when the state deems it is threatened in its existence, it has the right to subsist even if it does so by pushing back the limits of the law", in extremis, by putting to death those it declares its enemies (DP1a109).

Now one might here interrupt and say that this exposure of sovereignty to the unconditional event in no way justifies the death penalty as the legal putting to death; for first of all, there need be no enemy that threatens the sovereign with death; recall Derrida's objections to Schmitt on the grounds that the latter slides from the mere possibility of a mortal enemy to its actuality (Derrida 1997: 86). Even if there was an enemy, it could be combated by means other than killing, and if killing could indeed by shown to be necessary, he or she could be killed secretly, not necessarily as a result of legal procedures. While the Seminar, as we will see later, question this last point regarding the distinction between capital punishment and other forms of state-authorized killing, Derrida by and large agrees, I think, with these reservations. Indeed his attempts at formulating another logic of sovereignty in view of abolition point in this direction, even if here, at this point in the Seminar, he merely says that

this logic ... of absolute sovereignty and the self-preservation of the political body is going to authorize the absolute maintenance, although or because it is exceptional, of the death penalty, in the name of the self-preservation of the sociopolitical body. This logic is very solid, and very logical (DP1a109).

One might here also wish to distinguish the external from the internal enemy and argue that this logic would merely justify war, but not the putting to death of citizens. In 
response, Derrida points, again as in the Politics of Friendship, to the difficulty of distinguishing war between sovereign nations from civil war or Schmitt's "partisan war", not to mention here today's "war on terror" etc. For these reasons, indeed, Derrida argues that an abolitionism, such as Beccaria's, that aims at the elimination of capital punishment within a national territory during peacetime but maintains the right to kill in war, is insufficient and insufficiently principled (DP1a104; Derrida 2004: 152-3).

Above all, however, another inherited notion now comes into play to align political sovereignty with the death penalty as the legal putting to death of citizens: namely, the notion-Derrida dubs it "the classic philosopheme of all the great right-wing philosophies that have favored the death penalty" (DP1a148-9)—of death as proper to the human who only in his capacity to elevate himself above life, above 'mere' or 'animal' life, deserves to become a subject under law. The law must thus both express this elevated status as something the legal subject may lose (e.g., by becoming a beast below the human), and by demanding the life of the subject, either in war or as deserved punishment. In short, in these "classic" accounts of sovereignty, not legally putting to death would fail to treat the murderer as human (DP1a14). That is why Derrida regards the death penalty, by way of reading Kant and Plato, as the "foundation of the law" or the "quasi-transcendental condition of criminal law and law in general" (Derrida 2004: 145). In fact, he speaks of "the death penalty's paradoxical effect of transcendentalization that a consistent abolitionism must take on" (Derrida 2004: 142), paradoxical because like the sovereign exception and like the sovereign pardon, the death penalty is both internal to law (one of its laws) and external or excluded (a condition of possibility, a foundation, an origin). And that is why the death penalty is for Derrida the "keystone" of a theological- 
political matrix welded together (cf. Derrida 2004: 147-8) out of, first, a philosophical onto-theology that is seen, by Heidegger and Derrida, to dominate the history of Western metaphysics; second, a thinking of the political along the lines of the sovereign state; and third, a certain concept of what is "proper to man" as that which transcends his mere life, his dignity residing precisely in something above mere or bare life, in the ability to risk his life, a dignity to which justice relates and on which rational law (both moral and juridical) is founded. (This is why the deconstruction of the death penalty is to be related, as Michael says in a note (see p. 17, p. 29/30n25), to The Beast and the Sovereign, Derrida's Seminars from 2001-2002 and 2003, and the writings around the animal).

So the logic of exception, which puts the sovereign above the law that is to protect the life of its members, is here supplemented by this "classic philosopheme" to explain and justify the death penalty as the pinnacle of sovereignty. But despite this addition, and the possible non-sequitur from the logic of the exception to the need for the death penalty which it indicates in conjunction with the metaphysical idea of the humanity of the human as well as the lex talionis and the idea of equivalence between murder and capital punishment (Derrida 2004: 150-152), the theological value of the absolute must be thought beyond a merely historicist and semanticist reading. Derrida does not just assemble the contingent relations of force and historical elements of an institution or a practice in a genealogy à la Foucault, but inquires into the conditional and unconditional demands placed upon such instances. When it comes to sovereign power, Derrida most often turned to Carl Schmitt to make this point. Here, too, Schmitt is said to be right that we cannot understand sovereignty without the theological in a sense that exceeds, as Derrida clarifies, a mere genealogical "returning to the sources" (DP1a112). In a 
demonstration that is for me one of the hallmarks of the Seminar, anticipating and elaborating the claim in Voyous that to think reason means to think beyond it, Derrida effects this non-historicist clarification (or better yet, not-merely-historicist: for inheritance remains uncircumventable, inseparable from the concepts it brings forth) by contrasting Schmitt with Beccaria, pitting the conservative theologian against the progressive and "rationalist Enlightenment" thinker.

Both of them do not wish to limit the sovereign power of the state to preserve itself, but Schmitt thinks more consistently that self-preservation entails the right to the exception that suspends the law, with all the paradoxes and constitutive aporias this implies for the foundation of law. Beccaria, by contrast, wishes to abolish the death penalty but also maintain the sovereign right to self-preservation, so that he makes ad hoc exceptions to his abolitionism without developing a logic that can integrate these exceptions into his understanding of the law whose rationality and rule-boundedness he otherwise wishes to maintain. Thus Beccaria seeks to "reconcile reason and law" (DP1a117) but in this very (rational) reconciliation misses the non-rational and yet unconditional source of sovereignty in an exceptional decision. Of course, we already saw that Schmitt also misses something here, for this decision does not emanate from an already constituted sovereign power who knows in advance who the enemy is; rather the decision gives rise to sovereignty in being also a decision on the exception that "comes from the other" (DP1a4), exposing sovereignty to what we called unconditional errancy. Still, the drift here turns first of all against Beccaria, for we should learn from Schmitt that one cannot just maintain the sovereign right of the state to preserve itself and yet 
remain a straightforward Enlightenment rationalist, one who foregoes a thinking of "the theological" and the right to exception. ${ }^{4}$

In an extemporized comment at this moment in the Seminar, Derrida explains that thinking the theological in sovereignty here with Schmitt is not just to "go back to the sources":

When he [Schmitt] says that all concepts of the modern theory of the state are secularized theological concepts and one must know this not only historically in a genesis or genealogy, but also systematically, that is, in the logical articulation of these concepts, in order to understand, it is not a matter of merely returning to the sources. To understand how this functions, the concepts of the political; to understand how together they form a system, one has to think them as theological concepts. Only the theological can account for them. And this means, as he himself says, that a sociological or historical or empirical analysis has no chance of understanding what is going on there. Only a theologian, only someone who understands the theological necessity of these concepts, can understand the law... This is what Schmitt reminds us of. One must be a theologian in order to understand the modern theory of the state and, for example, the globalization [mondialisation] underway (DP1a112-113).

This is why it is important not to misunderstand the notion of theologico-political sovereignty in a semanticist-historicist way that may suggest the eventual overcoming of its unconditional exposure to alterity. This alterity is missed by a straightforward Enlightenment rationalism as much as by a historicism for whom theological concepts are only to be treated genealogically, as part of a contingent heritage. By contrast, a "systematic" thinking of "the theological" at least has a chance of registering the ungraspability captured, no doubt in highly misleading ways, in political theology's notion of god and its absolute sovereignty as precisely that, both the offspring of the most terrifying power and the unconditional exposure to an a-rational absolute, non-positive but constitutive alterity that harbours a promise of change. 
(2) This brings us to Derrida's attempt at a consistent and principled abolitionism, one that, as Michael suggests, is the explicit goal of the Seminar. Against Beccaria and all "utilitarian" defences of abolitionism, Derrida insists that such an abolitionism be willing to "limit sovereignty" (Derrida 2004: 144-145). As we just learned, this means not just to assert the abolitionist cause while granting the state its unlimited right to selfpreservation, in which case many can be put to death on a long list of exceptions (Derrida 2004: 149). But to "limit sovereignty" is first of all to think its limitedness, that is, as we saw, its continual re-emergence in and through the unconditional exposure to the event. To deconstruct, as always, is to show how a given phenomenon is conditioned by the quasi-transcendental 'infrastructures' that at the same time open the phenomenon up to its unconditional destinerrance or open-endedness. And this means proceeding from the ineluctable, and ineluctably performative or prescriptive, unconditional exigency to put into question all conditions and limited horizons a sovereign entity projects and calculates.

For deconstruction, if something of the sort exists, would remain above all, in my view, an unconditional rationalism that never renounces...the possibility of suspending... all conditions... and of criticizing unconditionally all conditionalities (Derrida 2005: 142/197).

This is not, as we know, a critique from the outside, relying on pre-given standards, but a reading that proceeds from the auto-deconstruction of sovereignty itself, its exposure to its other. To submit to unconditionality, then, is to take on all conditionalities that permit putting to death - without, however, placing trust finally in the achievability of a state of affairs without conditions, and so without trusting, as we will see, one's own good 
conscience, one's belief in not participating in cruel practices and in systems of capital punishment.

(a) First then would be, as we said, the critical questioning of empirical conditions that authorize putting to death, such as those of Beccaria, whose abolition still permits the death penalty in cases of war, or when the state is threatened, and so on (Derrida 2004:

149). Here, we must, as Michael points out, refer to other non-principled stances against the death penalty, such as the UN Declaration of Human Rights, which protects state sovereignty, and the US Supreme Court's decision of 1972, which outlaws the death penalty only if it constitutes "cruel and unusual punishment". In response to the abolitionism that makes abolition dependent on "order, peace, and security", Derrida appears at first glance to call for the principled "unconditional right to life" in order to avoid what he calls "a fundamental, structural hypocrisy of the abolitionist discourse in its present state" (DP1a120). In De Quoi Demain, Derrida says:

As long as an abolitionist discourse has not been elaborated and effectively accredited (and this has not yet been done) at the level of unconditional principles, beyond the problems of purpose, exemplarity, utility, and even the 'right to life', we will not be shielded from a return to the death penalty... The history of this problem is immense and complex: how to abolish the death penalty in a way that is based on principle, that is universal and unconditional, and not because it has become not only cruel but useless, insufficiently exemplary? (Derrida 2004: 137)

Note the suggestion here that the unconditional principle that Derrida is after will put us 'even beyond the right to life'. We will thus have to ask about the relation the right to life, even if unconditional, entertains with the unconditional openness that sustains and undermines sovereignty. 
(b) But first, responding to these non-principled stances by moving up to the philosophical plane of principles, a consistent and principled abolitionism must encounter and deconstruct those principled discourses in favor of capital punishment, such as Plato's, Kant's, and Hegel's, discourses which have a relatively easy time refuting conditional, empirical or utilitarian abolitionism (Derrida 2004: 150-152). I must leave for another time a closer examination of Derrida's arguments here against Kant in particular (but also, to a lesser and more complicated extent, against Blanchot). However, it is clear that this deconstruction would include the following points: (i) As already mentioned, the role of the death penalty both inside and outside the legal system; (ii) the problematic distinction between self- and hetero-punishment that Kant uses to claim that, if he properly responded to his human dignity, to his capacity to apply the categorical imperative to himself so as not to make an exception for himself, a murderer would condemn himself to death, in line with the lex talionis (an idea also very strong in Hegel, for whom penal law famously has to "honour the criminal as rational"; see $§ 100$ of The Philosophy of Right, a text not analyzed here by Derrida). (iii) Hence, the focus would also have to be on the connection between the construction of the legal subject and the dignity and rationality of 'man', in particular given the recent attempts, including Habermas', to re-ground human rights in rational dignity; ${ }^{5}$ (iv) and on the principle of equivalence according to which, as Kant argues, a harm done to another is inflicted, by way of the $a$ priori validity of the principle of universalization, on myself. ${ }^{6}$ (Toward the end, we will come back to the blurring of the distinction between suicide and the imposition of the death penalty.) This deconstruction, however important it remains, should also contend with the claim made by Otfried Höffe and many others that modern 
states have parted company with Kant here because they no longer justify penal law on the basis of the ius talionis but on the basis of prevention and resocialization (Höffe 1999). ${ }^{7}$ Derrida might see this as part of the auto-deconstruction of modern legal systems that philosophy has yet to grasp, for he charges that "never has any philosophy as such contested the legitimacy of the death penalty" (Derrida 2004: 146).

(c) On the principled plane, then, Derrida first of all encounters not philosophical but literary texts, chiefly those of Victor Hugo and Albert Camus. The former in particular puts forward a principle above the law, namely, an unconditional right to life; indeed, 'unconditional' is used in Seminar mostly in reference to Hugo (e.g., DP1a137, DP1b6169), although it is also used in reference to a principled position that is 'unconditional' in trumping, thus limiting sovereignty (DP1a 101, 118, 182). However, in Hugo's case in particular, the 'unconditionality' of the right to life appears compromised due in large part to its religious, Christian articulation. As Michael rightly stressed, to lay bare the decidely Christian articulation of the abolitionist discourse is one of the main goals of the Seminar (DP1b95). This articulation - and not only, as we will see, due to its monotheistic heritage — is beset by the following problems:

(i) First, like the sovereign, the writer grants himself the sacred right to suspend existing positive law in the name of divine law, a sovereign law (DP1a136, DP1b65). We thus slide from unconditionality (in this case, the unconditional right to life pitted against the political sovereign) back to sovereignty and its self-authorizing power. Perhaps, however, this claim to an absolute, unassailable, thus sovereign status, is as unavoidable as the fact that sovereignty is enabled by an unconditional errancy to which it must commit itself. At least this is what one may surmise given Derrida's treatment elsewhere of the 'university 
without conditions', whose claim to the right to criticize sovereign power Derrida characterizes as a "claim to independence, that is, to a certain very particular form of sovereignty" (Derrida 2002: 206-7). We must thus recall that to separate sovereignty and unconditionality remains an attempt at separating the inseparable, as Rogues had it (Derrida 2005: 141-2/195-196).

(ii) Hugo's and, to some extent, Camus' discourse remains part of a progressive "teleotheology" in which abolition is the goal of a history both made by (virile) men and guided by God as the author of human life (DP1a155).

(iii) Not only is the unconditional right to life limited to human life (DP1a130), but life is also conceived as the eternal property of the human (DP1a166). In Derrida's words, "the infinite protest against mortality and against one's own mortality, especially against what is held to be an unnatural death, is the mechanism driving all discourses on the right to life and the inviolable property of my life" (DP1a166). This ultimately religious discourse fails to take mortality and expropriation into account in the right way. However, we already understand that it is not easy, and not universally desirable, to do away with inherited religions as they give - albeit deconstructible — expression to functional exigencies, in this case the need for life to preserve and appropriate itself to itself by keeping death's alterity at bay—a need that may take many forms, from Heidegger's 'mineness' of death to some convicted murderer's attempt to control their execution (DP1a78), blurring the distinction between suicide and the death penalty in reality as Kant did in legal theory (Derrida 2004: 150). This would also explain why Christian discourses on eternal life are profoundly ambiguous: downplaying death may lead, as in Hugo, to the unconditional affirmation of an eternal life connected to divine 
sovereignty and law, but it may also support a "banalization" of the death penalty (DP1b146), for it allows the executioners to believe that by putting to death the murderer, they merely hand him over to God's judgment. To tackle this profound ambiguity of Christianity as being both for and against the death penalty, Derrida pits Nietzsche against Kant (DP1b7-44) and Baudelaire against Hugo: "this wish to be done with legal killing would testify, according to Baudelaire, to the fact that I am always calculating my salvation" (DP1a167). Derrida concludes that Hugolian abolitionism shares too much with a Christian humanism that is to be deconstructed by an unconditional abolitionism.

(d) An unconditional abolitionism would thus have to seek to suggest—and I think here the most work in elaborating Derrida's Death Penalty Seminar remains to be done-an unconditional principle, or if not quite that, then at least a principled position that keeps in mind the following:

(i) Founding an unconditional principle on human dignity as the indispensable counterpoint to law opens itself to the "right-wing philosopheme" (DP1a147-8) according to which a murderer's 'dignity' is only properly 'honored', as Hegel put it, if the law reconstitutes itself by condemning him to death. ${ }^{8}$

(ii) Further, the consistent abolitionism aims at an unconditional principle that is not limited to the human, perhaps not even—not from the beginning and always, as if beyond questioning-limited to the living. The reason here is not just that the unconditional abolitionism should also concern itself with animal life, but that a philosophical stance against the death penalty must interrogate the limit between life and death and the power supposedly sovereign human agents have in the face of this limit, as regards both the knowledge of it and the power to inflict it. Attentive readers of Derrida will not be 
surprised to find that the Seminar, in part by referring to the texts on Freud in The Post Card and the 1975 Seminar "Life/Death" out of which they emerged (DP1b31), suggests that an unconditional abolitionism should understand life as 'life/death' (Derrida 1987: 292) or what Derrida frequently calls 'sur-vivre', life as living-on with death as not exterior to it, as if life was indeed the 'inviolable' property of its bearer, but life as "suffering a thousand deaths" (DP1b130).

In the few remaining comments here, I discuss the consequences for abolitionism of conceiving life as survival, as la vie la mort (Derrida 1987: 259). I think only this will allow us to understand the double-edged conclusion to the first year of the Death Penalty Seminar:

Let us harbor no illusion on this subject: even when it will have been abolished, the death penalty will survive, it will have other lives in front of it, and other lives to sink its teeth into. But sustaining no illusion on this subject must not prevent us - this is courage and composure [le sang-froid] — from being militant, from organizing with cool heads [de sang-froid] to militate, while waiting, for what is called the abolition of the death penalty, thus for life, for survival, in the priceless interest of life [note that there is no reference to 'dignity' here], to save what is left of life (DP1b182-3).

Derrida's abolitionism seeks to be for life as survival, and militantly so, even with the awareness of the need for patience in waiting for movements and currents that it cannot control, that may take years, decades, centuries. Above all, however, in harboring no illusions the deconstructive abolitionism, like all goal-directed action and all political movements claiming to work toward justice, must seek to avoid the development of a good conscience about itself and with regard to its goal. For even if abolitionism were to achieve the universal abolition of the death penalty—Derrida defines this as a state of affairs in which "states consent to abandon sovereignty and to appear before an international criminal court that refers to a legal text condemning a state for putting to 
death a subject" (DP1a102) - the death penalty, says Derrida, should be understood to survive. How can this be?

It is not only that Derrida fears reinstatement in times of great social upheavals (Derrida 2004: 137). It is also not just, though this gets a little closer, that Derrida believes sovereign states will reserve the right to kill perceived enemies, whether citizens or not, even if they abolished legal putting to death. (Both of these points may be seen at play in the near-total equanimity in the face of the US executing Anwar al-Awliki from a drone plane in Yemen at nearly the same time as millions around the world are protesting the execution of Troy Davis in September 2011. ${ }^{9}$ ) It is also not just that Derrida formulates an unconditional abolitionism that includes a principle of the right to life referencing "the living in general" (Derrida 1995b: 289/293), though the parallel at the end of the Seminar's first year between abolitionism and vegetarianism (DP1b182), in terms that recall "Eating Well" (Derrida 1995b), may seem to suggest this kind of concern.

There is, however, another kind of argument, perhaps more philosophical, that inflects the patience expected of this abolitionism. Although this argument, too, deserves much more scrutiny than this initial response to the Seminar can devote to it, it should not be overlooked. Approached most closely in Session 9 (DP1b102-132), the key idea is that death is not only integral to life, but marked by an unmasterable alterity to which life remains passively exposed even as it dreams of giving death to itself or to others. We should then hear the claim with which the Seminar begins, as already discussed — the claim that the sovereign decision on the exception, and hence on death, is always the decision of the other (DP1a4) - in a new key. Let me cite what I take to be the conclusion 


\section{to Session 9:}

Wherever is lacking at least the presumption of knowledge on the subject of this so-called objective limit [between life and death], this end of life (which Heidegger would make us believe is not the dying proper to Dasein), wherever this mastering calculation is no longer presumed accessible, possible, in our power, well then, one could no longer either speak of murder, suicide, and death penalty, or organize anything of the sort whatsoever in the law, in the legal code, in the social order, in its procedures and its techniques, and so forth (DP1b128).

As Derrida refers here repeatedly to his deconstruction of Heidegger (and Levinas) in Apories and in Donner la mort, a full discussion would re-read these dense texts. We may begin by noting, however, that the point is not to simply equate suicide, murder, and the death penalty; different cultures and different histories of death, as Aporias says (Derrida 1993: 43) and the Seminar recalls, may come to set up distinctions that, however, remain deconstructible. Such deconstructions take as their object the "common sense" presupposition of an objective, given limit between life and death by referring to a "point of originarity" (DP1b127) prior to these distinctions, a (nonpresent) point at which death may be seen to come from an alterity that exposes as utterly passive the sovereign subject aiming at mastery of its uncharted mortal future.

And if we do not know what death is, and its arrival involves a moment of inexplicable alterity not at the disposal of sovereign subjects, a decision of the other rather than an agent, then at this point of originarity it will be hard to distinguish between a subject giving itself death and being given death; with reference to the latter, it will also be difficult to distinguish between the others giving death, the murderer and the executioner. In a complex and multifarious discussion, Derrida assembles a range of indicators that I think seek to reveal this point of originarity at work in and around the death penalty and its cultures, indicators that may serve as premises for the conclusion as 
to the deconstructibility of the distinctions among suicide, murder, and the death penalty.

First, at this originary point, we do not know 'what' death is and cannot pin-point the objective moment in time that separates the living from death; indeed, at this point we may not trust the self-coincidence of time that would allow this objectivity. In the Seminar, Derrida refers to the multiplicity of criteria characterizing the moment of death, criteria differing from one society to another as well as from one time to another (DP1b128); even within one society at a given time, for instance the US, various criteria compete, such as brain death, the end of respiration, and heart stoppage (DP1b131). Second, we already referred to Kant on the indiscernibility of suicide and the death penalty: executing a murderer would be suicide because a murderer, to the extent he is a dignified rational agent, must be understood as applying the principle of universalization, and this principle implies that whoever murders another murders himself. Third, this indistinguishability may also be detected in some empirical cases. Referring to Freud's theory of the death drive (DP1b68) that Derrida discusses extensively in The Post Card in connection with life/death, the Death Penalty Seminar refers to murderers who, in killing others, wished for their own death, or a death of a part of their selves (for life/death multiplies selfhood). The paradigm here is the case of Buffet, famous in French abolitionist discourse, whose murder was said to be suicidally driven (DP1b68) and who became fascinated with controlling his execution by the guillotine in the early 1970 s. This gives rise to an argument of sorts against the allegedly deterring effects of the death penalty, for public executions may generate their private imitators, "a kind of perversion of the Imitation of Christ" (DP1a78). Fourth, the death drive aims, according to Freud's Beyond the Pleasure Principle, not at any death but a proper, internal death, and so is 
animated by the dream of absolute auto-affective power. Derrida's reading of this distinction between the internal and external death of an organism places it in différance (Derrida 1987: 285, 353-61). Hence, we meet here the indistinguishability of the forces of life and death, and so of the (Hugolian) desire for eternal life and the suicidal dream of giving oneself death. As a fifth (and for now final) pointer, Derrida argues for the difficulties besetting the distinction between murder and legal putting to death by saying that murderers, too, typically give meaning to their acts by justifying them, however selfrighteously, thus appealing to some universalizable law (DP1b117-8).

This then may return us to the sovereign subject in its relation to life and death. To seek to preserve oneself is to affirm one's possession of agential powers, and psychologically, this will most often usher in the development of a good conscience. We know in advance, however, that it cannot be entirely justified, for the structure of selfhood cannot be had without cruelty. We said at the outset that the sovereignty or power of agency requires a welcoming gesture toward an other that, however, also threatens it with its demise. The meaning of this alterity, in particular at a certain point of originarity, ranges from the self as other to itself to other selves, from the life-sustaining context to death. In affirming itself, the self affirms the other that it must also keep at arm's length. The welcome extended to the other is also a gesture of appropriation and repression, for example of other selves and other voices in the self. As a result of this conflictual structure of selfhood, the Seminar cautions with Nietzsche, Freud, and Lacan, cruelty is necessary for the self to be formed, and the claim to noncruelty, for instance Beccaria's or Hugo's, hides more or other forms of cruelty (DP1b31).

An unconditional abolitionism, even if seeks to elaborate a "promise of 
nonviolence" in welcoming the other (Derrida 1996: 83), may then not pretend to be a "revolt of innocence" (DP1b41). If there is no one unitary, objective death (DP1b130), there is not just one death sentence (arrêt de mort) — that is why the death penalty will survive (DP1b182). This is so especially if we understand that the radical passivity that confronts subjectivity with mortality, its own and that of the other, undermines any facile and comforting distinction between imposing harm and refraining from assisting others. In the Seminar, Derrida refers to AIDS around the world as a case in point: its existence spells “another form of 'death sentence', with all the quotation marks you wish", even if the "crime" in this case, the failure to help someone in danger of dying, is "passive" (DP1b45). Similarly, in Donner la mort Derrida argues that world hunger makes of murder "the most common event in the world", albeit an event covered over by so-called "civilized" societies whose "good conscience" often includes the abolition of capital punishment while the "monotonous complacency of its discourses on morality, politics, and the law" are unperturbed by the fact that the laws of the global market these societies set up and control lead to another form of the death sentence, putting to death or- $-\mathrm{a}$ "minor difference"—allowing to die many of hunger and disease (Derrida 1995a: 85-6). This shaking-up — not a simple erasure but critical, philosophical interrogation — of the distinction between active and passive, between the negative duty not to harm and the positive duty of beneficence that would have to be elaborated here, may be read as a contribution to the debate that has grown around Thomas Pogge's World Hunger and Human Rights, which famously argues that affluent Western liberal democracies are harming the world's poor, for example through the 'resource' and 'borrowing' privileges which allow undemocratic and often corrupt governments to sell natural resources and to 
borrow money in the name of the country and its people (Pogge 2008; for the debate around negative and positive duties, see Gilabert 2005).

In taking seriously these other kinds of death sentence, the deconstructive deathpenalty abolitionism remains vigilant with regard to its own conscience. It takes its unconditional renunciation of sovereignty, its opening to the decision of the other, to be only one moment of its nonvolitional double affirmation, the other consisting in its slipping into a sovereignty and survival of its own as well as that of the modern state and the law on which it depends and which it seeks to modify. Realizing the exigency of the unconditional renunciation is not to put faith in progress. But in contesting the sovereign's 'theologico-political' dream of closing itself to the decision of the other, it may contribute to the betterment of the law.

\section{Bibliography}

Connolly, William. 1995. “The Desire to Punish” in: The Ethos of Pluralization, Minneapolis: University of Minnesota Press.

Derrida, Jacques. 1987. The Post Card. From Socrates to Freud and Beyond, trans. Alan Bass. Chicago: University of Chicago Press.

------. 1993. Aporias. Dying--awaiting (one another at the "limits of truth"), transl. Thomas Dutoit. Stanford: Stanford University Press.

------. 1994. Specters of Marx, transl. Peggy Kamuf. London: Routledge (Spectres de Marx. Paris: Editions Galilée, 1993)

------. 1995a. The Gift of Death. Translated by David Wells. Chicago: The University of Chicago Press.

------. 1995b. Points...Interviews 1974-1994, ed. Elisabeth Weber, trans. Peggy Kamuf and others. Stanford: Stanford University Press (1992. Points de suspension. Paris: Editions Galilée.)

------. 1996. "Remarks on Deconstruction and Pragmatism." In Deconstruction and Pragmatism, edited by Chantal Mouffe. New York: Routledge. 1997. The Politics of Friendship. Translated by G. Collins. London: Verso. (Politiques de l'amitié. Paris: Editions Galilée, 1994).

------. 2002. Without Alibi, trans. Peggy Kamuf. Stanford: Stanford University Press.

-----. 2004. For What Tomorrow...A Dialogue, with Elisabeth Roudinesco, trans. Jeff 
Fort. Stanford: Stanford University Press.

------. 2005. Rogues. Two Essays on Reason. Translated by Pascale-Anne Brault and

Michael Naas. Stanford: Stanford University Press.

------. (forthcoming). Seminar Pardon-Perjury: The Death Penalty (1999-2003), trans.

Peggy Kamuf, ed. Geoffrey Bennington, Marc Crépon, and Thomas Dutoit. The first five sessions are cited in the text as DP1a, sessions six to eleven as DP1b.

Fritsch, Matthias. 2008. "Antagonism and Democratic Citizenship (Schmitt, Mouffe, Derrida)" Research in Phenomenology 38:2, 174-197.

------. 2011a. "Deconstructive Aporias: Quasi-Transcendental and Normative" Continental Philosophy Review 44:4, 439-468.

Gilabert, Pablo. 2005. "The Duty to Eradicate Global Poverty: Positive or Negative?" Ethical Theory and Moral Practice 7:5, 537 - 550.

Habermas, Jürgen. 1987. The Philosophical Discourse of Modernity. Twelve Lectures, transl. Frederick G. Lawrence. Cambridge: MIT Press.

------. 2010. "Das Konzept der Menschenwürde und die realistische Utopie der Menschenrechte" Deutsche Zeitschrift für Philosophie 58:3, 343-358.

Höffe, Otfried. 1999. "Vom Straf- und Begnadigungsrecht" Immanuel Kant: Metaphysische Anfangsgründe der Rechtslehre, ed. Otfried Höffe. Berlin: Akademie Verlag.

Menke, Christoph. 1991. Die Souveranität der Kunst. Ästhetische Erfahrung nach Adorno und Derrida. Frankfurt: Suhrkamp.

Naas, Michael. 2008. Derrida From Now On. New York: Fordham University Press. Pogge, Thomas. 2008 ( $1^{\text {st }}$ ed. 2002). World Poverty and Human Rights: Cosmopolitan Responsibilities and Reforms. Cambridge: Polity Press 2008.

\section{ENDNOTES}

\footnotetext{
${ }^{1}$ I do not mean to attribute this reading to Michael. It would be, rather, one we find in some prominent friendly interpretations of Derrida (permit me to refer to Fritsch 2011a for a more detailed analysis), but also of course in Habermas (in The Philosophical Discourse of Modernity), where Derrida is accused of deconstructing only the metaphysical absolutes that history is said to have already put aside (Habermas 1987: 408-9, cf. Menke 1991: 226ff.).

${ }^{2}$ As différance permits no undifferentiated unity, the sovereign, indivisible self is thus as "phantasmatic" as is the determination of the "enemy", as Michael showed so well in his "Comme si comme ça" (in Naas 2008).

${ }^{3}$ Thus the basic outlines of the auto-deconstruction of Schmitt's texts: the ineluctable lack of knowledge and indeed constitutive undecidability as to who the enemy is (Derrida 1997: 69, 106); the becoming-internal of the enemy, from another sovereign state to the domestic enemy to the brother to, finally, the self as its own enemy (Derrida 1997: 162); the convertibility of friend and enemy (Derrida 1997: 32, 71, 88, 174); and Schmitt's slide from possibility to eventuality to the actuality of war and physical killing (Derrida
} 
1997: 86). For a more detailed interpretation, permit me once more to refer to Fritsch 2008.

4 "Basically, upon hearing this declaration, one could say, in order to grasp the most interesting difference between a thinking of this type (a thinking of Enlightenment and Reason) and a thinking like Schmitt's, that the latter attempts to think this "authority," this auctoritas and this potestas, this power of the constitutive power of sovereignty and of its theological history, whereas Beccaria, by saying he prefers reason to authority, basically deprives himself of the means of understanding this logic of sovereignty to which he is nevertheless not opposed. He would like to reconcile reason and right or law, where Schmitt, in a manner that is just as rational and logical, recalls that the origin of the law, like the origin of reason, cannot be legal or rational, and this is the source of authority, its always exceptional source.” (DP1a117)

${ }^{5}$ Habermas (2010) begins by citing the first article of the 1948 UN Declaration, which refers to human dignity, as does Article 1 of the German constitution. Derrida also notes that dignity is indeed claimed by both sides of the abolitionism debate (DP1b6-7) and recognizes that the UN Declaration, while permitting the death penalty, aims at its eventual abolition grounded on dignity (DP1a174).

${ }^{6}$ In order to cast doubt on this equivalence, in fact any equivalence between crime and punishment, Derrida discusses Nietzsche's genealogy of morals (DP1b20-28). This discussion culminates in the Nietzschean diagnosis that Kant's categorical imperative, the one that also grounds Kant's stance on the death penalty for murder, "stinks of cruelty" (DP1b30), and reminds us that Beccaria argued in favour of abolitionism by pointing to the greater cruelty of life-long forced convict labour (DP1b32). On problems with the principle of equivalence, see also Vernon Thomas Sarver Jr., "Kant's purported social contract and the death penalty" The Journal of Value Inquiry 31: 455-472, 1997.

${ }^{7}$ Without taking this into account it would be hard to understand why the death penalty has been declared unconstitutional in some European jurisdictions, at times with the justification that it conflicts with human dignity. This is the case, for example, for many jurists in Germany who ground the 1949 elimination of the death penalty (Article 102 of the German Constitution, or Grundgesetz, GG) in human dignity (Article 1 "The dignity of human beings is unassailable", an article protected from parliamentary change by the so-called Clause of Eternity, GG 79.3) or the right to life (GG 2.2). See the discussion by the German jurist and later German President Roman Herzog: Todesstrafe I. Rechtlich B. Verfassungsrechtlich, in: Evangelisches Staatslexikon Volume 2, Stuttgart 1987, p. 3615. In these cases it would hence be harder to claim, as Derrida does with regard to France, generalizing to Europe, that we must fear popular calls for reinstatement, the reason being that abolition in Europe did not result or not only result from "reasons of principle" but because people thought they did not need it any more, such that social upheavals could lead to its reinstatement (Derrida 2004: 137). 
${ }^{8}$ The unconditional principle would put to test a tradition much broader than the death penalty, relating in particular to the courage in war that a politicaly community might expect of its (virile) citizens. I have in mind the Greek and Christian claim that there is something higher in human life than its merely natural life, that this something higher thus assigns a price to life, as Aristotle put it (Nicomachean Ethics IV.3 1124b6-9; cf. Plato Laws 727d), and that, we might add in this context, the law, the sovereign executor of the law, is the judge as to when this price is to be paid.

${ }^{9}$ One may also think that legal and 'extra-judicial' putting to death are worlds apart, even if in both cases the death sentence is carried out in the name of a politically organized community, represented by a sovereign. If we recall that in both cases the sovereign could have granted pardon, from the sovereign's point of view the distinction would then hinge on the difference between a supposedly 'active' order, secret in the case of

President Obama's death sentence of al-Awliki, and the more 'passive' signing of a death warrant on the part of a Governor. From the point of view of the subject put to death, it may seem that 'due process' would make all the difference, though even this difference might decrease if we agree with Derrida that it is next to impossible to prevent the legal process from being severely compromised by cruel and vengeful passions (DP1b118), often racist (DP1a95), overtly or covertly, as in the case of Troy Davis. For another very subtle Nietzschean analysis of the racism in the US justice system and the institution of the death penalty, see Connolly 1995. 